\title{
Critical Review of Public Organ Donation Education Programs
}

\author{
Félix Cantarovich MD PhD \\ Faculty of Medical Sciences, Catholic University of Argentina \\ 9, rue Parent de Rosan, 75016 Paris France \\ Email: felix.cantarovich@orange.fr
}

\begin{abstract}
The persistent organ shortage shows that many people remain unresponsive to this dilemma. Increasing waiting list mortality notwithstanding social education has remained unchanged. The slogan considering that organ donation "is a gift of life" persists as the primary catchphrase on education campaigns. Fear of death, mutilation, distrust of medical teams and religious uncertainty are possible barriers to donation along with lack of information and education on what organ transplants mean nowadays for society. People's acknowledgment of slogans such as: "Throughout our lives we are all potential recipients of organs and tissues"; "The body after death is a unique source of health for all" and the catchphrase"; Sharing the donated organs could be a social agreement", should be considered as expression of promising educational programs. Finally, a curricular programming in donation and transplants in schools and universities will be an important contribution in the search for solution of this critical problem.
\end{abstract}

Keywords: Criticism of social donation education. Organ shortage. Barriers to donation. Waiting list mortality. Donation in schools curricula.

\section{Background}

We are into the 21 st century and the rate of patient mortality on transplant waiting lists is increasing every year. Undoubtedly the main factor in this crisis is the persistent shortage of organ donors (Shmugarajahadan, Villania; Madariaga, Shalhoubd, Michelab, 2014). In the search for reasons why people are reluctant to donate it is important to consider the possible role of social education programs, which have remained the same for several decades. Although the need for a thoughtful change in approach to social education has been pointed out, organ donation educational events continue to rely on the classic slogan, that organ donation is a "gift of life" (Cantarovich, 2004; Humphries, Conrad, Berry, Reed \& Jennings, 2009). Suggestions for changes to social education programs have not yet been considered by those responsible for the best practice of this medical activity. (Mocan, Tekin, 2007; Hanto, Peters, Howard \& Cornell, 2005; Verheijde, Rady \& McGregor, 2007). So far suggestions for ways of tackling the crisis have been based on medical innovation or changes to the law.

\section{Legal solutions}

\section{Presumed consent}

France was the first country to change the law on organ donation, introducing "presumed consent" to donation in 1978. The law establishes that if refusal to donate is not recorded in an official document a person is considered a potential donor. Spain has also introduced a presumed consent law. In fact, this legislation has not been applied in both countries. The French Republic has recently approved a modification of its laws on organ donation.

It is important to note that Spain's remarkable progress on organ donation is essentially the result of its efficient health policy on transplantation, particularly the efforts of hospital coordinators (Matesanz \& Miranda, 1995).

The limited popular response to appeals for donation has led to laws on presumed consent being introduced in many countries, but until now the results of such measures have been controversial. It is certainly difficult to define the significance of this legal modification of consent, particularly in the case of the deceased donor (Abadie \& Gay, 2006). It is important to consider the ethical and philosophical implications of the introduction of a legal presumption of consent to donation. Individual autonomy is generally understood as the right to be one's own person, to live one's life according to one's own values and not be subject to manipulation or distorting external forces. The concept of autonomy is central to debates on biomedical ethics, legal rights, moral education and political theory (Dalal, 2015). In moral theory, frameworks in which autonomy is a central value can be contrasted with alternative frameworks based on ethic of care, utilitarianism of some kind or an ethic of virtue (Stanford Encyclopedia of Philosophy, 2015). 
Concerning legal modifications of consent donation, particularly in the case of the deceased donor, we believe that a well thought-out education will be more effective than legal instruments to overcome the ancestral people's behavior reveres towards their loved ones at the time of death.

\section{Economic incentives to donate}

Considering that legal economic incentives to donors or donor's families might be significant option to improve society behavior to organ donation, an Economy Nobel prize suggestion to institute legal incentives to donation has gained significant worldwide interest (University of Chicago Medical Center, 2003; Becker \& Elias, 2007; Tabarrok, 2001). The moral and ethical risks attached to acceptance of this initiative include the possibility that placing a price on a human body might generate a dramatic social inequality between the poor and the rich. . In the analysis of this proposal it have been argued that it would not be unethical to provide an economic incentive to encourage deprived individuals to donate, particularly when their organs might save lives (National Kidney Foundation, 2003; Van Dijk \& Hilhorst, 2007; Deck \& Kimbrough, 2013).

In addition, it has been suggested concerning this initiative, the institution of a clear legislative framework and strong governmental control of the transparency of the procedures as well of donors and recipients protection. The greatest threat to a regulated system of donor's incentives would be that dishonest individuals or groups would seek to subvert the system for personal gain, a risk that applies to any legal enterprise (Working Group on Incentives for Living Donation, 2012).

\section{Medical solutions}

The persistent increase in patients "dying unfairly" on transplant waiting lists, in spite of progress in the long-term survival of transplanted organs and patients has led to a substantial change in the medical criteria for acceptance of organ donors:

\section{Paired kidney exchange program}

This program involves matching pairs of potential donors and recipients, where there donor and recipient making up one pair are immunological mismatched. This program will to enable compatible donors to give a kidney to the compatible recipients in each pair. This new approach for living, related donors will allow patients with ABO blood group incompatibility or with a positive cross match test with their donor to be transplanted with a compatible donor from another family. It will allow recipients to receive a compatible donor and allow potential donors to realize their wish to donate (Rapaport, 1986).

This program was not implemented clinically in the United States and Europe until the late 1990s, after a broad ethical and social debate. The results, based on data from multiple centers at regional and national level in terms of graft survival, recipient rehabilitation and donor satisfaction are excellent. An international activity of this program is presently being scheduled to be developed. (Ross, Rubin, Siegler, Josephson, Thistlethwaite \& Woodle, 1997; Montgomery, Zachary, Ratner, Segev, Hiller, Houp \& Warren, 2005; de Klerk, Keizer, Claas, Witvliet, HaaseKromwijk \& Weimar, 2005; Beom, Yu, Soon, Myoung., Ho, Yong-Lim, Le, Kim, Kim, Yang, Choi, Han, Kim, Kim, Oh \& Kim, 2007; Gentry, Segev, Simmerling, Montgomery, 2007; Gebel \& Bray, 2008).

\section{Donation after cardiac death (DCD)}

Organ transplantation with favorable results began fundamentally with the use of living donors. During the first decades of the 20th century cadaveric donors were exceptional.

Current transplantation practice is governed by the dead donor rule: non-paired vital organs can only be retrieved from patients who are dead. Most transplantable organs come from patients who are declared dead on the basis of neurological criteria. These patients are called beating-heart donors (Robertson, 2012).

However, the critical lack of organs and the technical advances made by organ procurement organizations have made possible the use of DCD, or non-heart-beating organ transplantation. A DCD is an organ from a donor who has suffered devastating and irreversible brain injury, but does not meet formal brain death criteria and whose family has decided to withdraw care. Organs from DCD have suffered some degree of oxygen deprivation and so the risks of primary renal failure or functional delay of the graft are greater.

DCD is accepted in international medical practice as it is estimated that it could increase the supply of donor kidneys by $20 \%$ as well as increasing the supply of other solid organs including liver, pancreas and pancreatic islet cells (Dinh, Monard, Delbouille, Hans, Weekers, Bonvoisin, Joris, Lauwick, Kaba, Ledoux, de Roover, Honoré, Squifflet, Meurisse \& Detry, 2014). 


\section{Expansion of the range of donors}

The crisis in organ supply has induced a reconsideration of the criteria for accepting donors, although the relaxation in criteria may reduce the chances of successful transplantation. This change in medical criteria involves the acceptance of donors currently known as expanded criteria donors (ECD). These donors were previously called marginal or suboptimal, because the long-term results of their donations were lower than those obtained with standard donors. ECDs are normally aged 60 years or older or over 50 years with at least two of the following conditions: hypertension history, serum creatinine $>1.5 \mathrm{mg} / \mathrm{dl}$ or death due to cerebrovascular accident. They are also referred as donors with medical complexities. (Alexander \& Zola, 1996).

The decision to use an ECD kidney is complex, because these kidneys have a higher rate of primary non-function, delayed graft function, rejection and a greater susceptibility to preservation injury, drug toxicity and the effects of posttransplant hypertension. Furthermore, the estimated longevity of an ECD kidney might be a half-life of 6-8 years compared with 10-12 years for a standard deceased donor kidney (Ojo, 2005). However, given that organ transplantation results with ECD significantly allows for greater patient survival than a long-term on the waiting list and considering the persistent organ shortage, the acceptance of these donors is fully ethically justified (Cronin, 2013).

\section{Society's response to transplantation and organ donation education programs}

One of society's contemporary incongruities is that the success of organ transplantation is increasing whilst waiting list mortality is also increasing. Almost inexplicably, people's educational approach to improve the supply of organ donation has remained largely unchanged.

Although it has been suggested that an effective educational strategy could change attitudes and behaviors regarding organ donation, this initiative has so far never been attempted (Davis, 1991). As well, it has been mentioned that new educational measures are needed to reduce the massive gap between organ supply and demand (Chatterjee, Venkataraman, Vijayan, Wellen, \& Martin, 2015).

Although several polls have shown that $85 \%$ of Americans approve of organ donation, less than half have made a decision about donating and only (28\%) have granted permission by signing a donor card. The following items of information provided by United Network of Organ Sharing (UNOS) are highly significant: a) patient waiting lists grew from 23,198 in 1991 to 115,000 in 2017 ; b) the number of organ donors increased from 6953 in 1991 to 16,473 in 2017; c) the number of transplants increased from 15,756 to 34,770 over the same period (US Department of Health and Human Services, 2018). It is clear from over 26 years of US data that, unfortunately, the relationship between waiting lists and organ transplants remains practically unchanged.

In addition, the broadcast media often report harmful misinformation about clinical death and illegal transplantation and this should also be taken into consideration when evaluating the reasons for the lack of public response to organ donation campaigns (Aykas, Uslu \& Şimşek, 2015; Morgan, Harrison, Long, Afifi, Stephenson, \& Reichert, 2005).

Changing how people are educated about organ donation is one possible way of dealing with the critical shortage of donors. Efforts to change social education programs should also be supported by the main international medical societies, as well as the World Health Organization, UNESCO and representatives of all monotheistic religions.

\section{Potential causes of the lack of social response to organ donation campaigns}

First and foremost we must consider whether the continued use of the slogan "organ donation is a gift", which has been the cornerstone of social education programs for decades, is justified.

It has been noted that although lack of awareness and misinformation, always considered major causes of the lack of social response to donation, they are not the critical barriers to organ donation. There is evidence that non-cognitive factors play a greater role in the final decision about whether to donate (Morgan, Harrison, Afifi, Long \& Stephenson, 2008a; Morgan, Stephenson, Harrison, Aifi \& Long, 2008b).

It has been shown, for example, that psychological beliefs such as fear of death or mutilation and a distrust of medical behavior are the strongest barriers to donation (Morgan, Harrison, Afifi, Long, \& Stephenson, 2008b; O'Carroll, Foster, McGeechan, Sandford, \& Ferguson, 2011). It has been pointed out that fear of death is the concern that most inhibits a person in deciding donation, mainly due to a lack of experience with dying people. This inexperience makes it difficult for people to discuss organ donation with family members. The subconscious fear of death emerges with the death of a loved one, and further intensifies the pain of that moment. (Morgan, Harrison, Long, Afifi, Stephenson \& Reichert, 2005; Newton, 2011; Thagard, 2012).

There has been very little specific research on treatments for fear of death and anxiety about health. The main components of such treatment are exposure to themes related to death, reducing safety behaviors, cognitive reappraisal and focusing more on goals and enjoyment of life (Furer \& Walker, 2008). 
We suggest that one potential way to overcome the strong non-cognitive barrier to donation that is represented by fear of death would be to adopt in educational programs the slogan "When life is gone, our body becomes a unique and irreplaceable source of health for all".

It is interesting to note that despite the importance assigned to non-cognitive factors as a barrier to donation, ways of modifying these long-established inhibitions have yet to be evaluated.

Given that non-cognitive factors represent a strong influence on social behavior towards organ donation, we suggest including the following messages in future social education programs.

1) The shortage of organs is a health emergency.

2) Throughout our lives we are all potential recipients of organs and tissues.

3) The body after death is a unique source of health for all.

4) Organ donation is not giving a life, it is sharing life.

5) "Sharing the donated organs could be a social agreement"

Well-organized public education campaigns, based on detailed analysis by social communicators, psychologists and religious experts, might be useful in overcoming the strong non-cognitive barriers to donation and offer a way to address this persistent, global health crisis.

\section{Results of university education programs on transplantation and donation}

Several studies through the years have shown the insufficiency of university medical training on the critical problem of the lack of organs (Radunz, Benkö, Stern, Sane, Paul \& Kaiser, 2015). A survey of 2321 university students who have benefited from previous organ donation information campaigns was performed in five countries, Argentina, Brazil, France, Italy and Austria, to assess views on organ donation and new proposals on educational strategies. First and foremost, organ shortage was considered a serious public health problem. The widespread ignorance of religious precepts concerning transplantation in Catholic countries was also notable. Most respondents considered organ donation to be a gift, but many of them accepted the concept that donation means sharing body parts after death. The proposal to offer economic incentives to donors or their families was widely discussed by the participants. A significant positive result of this survey was the high acceptance rate of educational programs in schools. These results suggested that it is important to ensure the participation of leaders of monotheistic faiths in educational programs about organ donation (Cantarovich, Heguilen, Abbud Filho, Duro-Garcia, Fitzgerald, Mayrhofer-Reinhartshuber, Lavitrano \& Esnault, 2007).

A survey of medical professionals undertaking post-graduate studies in various medical areas is currently being carried out by the Catholic University of Buenos Aires to provide an up-to-date picture of this group's knowledge about the organ shortage problem. (Cantarovich, 2018) The survey consisted of two questionnaires. The first one aimed to assess the knowledge of donation and transplants in medical professionals of a country that has had a national transplant program since 1979 (Cantarovich, Bacqué \& Casadei, 2000). The second poll analyzed acceptance of the new concepts and slogans proposed in this manuscript, particularly the extent to which cognitive and non-cognitive factors act as barriers to donation.

The questionnaires were completed by 159 professionals, 88 females (55.35\%) and 71 males (44.75\%) with an average age of 37 years (range: 27-64). Responses to the first questionnaire show that current university medical instruction in transplantation has remained largely unchanged and is inadequate. The second questionnaire showed $98.2 \%$ acceptance of the new concepts, particularly the value as donation inhibitions of non-cognitive factors, and the participant's intention to transmit these new concepts to their family and friends. (Cantarovich, 2018). This preliminary study suggests that it is important to revise and extend coverage of donation and transplantation in university medical curricula (Abouna, 2008; Cornwall, Schafer, Lal, D’Costa, \& Nada-Raja, 2015; Bardell, Hunter, Kent \& Jain, 2003; Essman \& Lebovitz, 2005; Bardell, Childs \& Hunter 2002).

\section{Youth education on organ donation and transplantation}

Organ donation education for young people, beginning in primary school and continuing at college and university level, has been suggested as a promising method of changing social attitudes and behavior with respect to organ donation (Shoenberg, 1991). The rationale for this proposal is that young people are free of prejudice and may learn new ideas more easily than adults. Current psychology suggests that childhood is the best stage of life at which to prevent the development of social prejudices. It has also been highlighted that children who learn new ideas in school may transfer them to their families (Aboud, Tredoux, Tropp, Spears Brown, Niens \& Noor, 2012). In this regard we have carried out some interesting investigations in Argentina and Canada. An educational program dealing with the essentials of organ donation, procurement, and allocation was delivered to more than 1000 public school students from diverse socioeconomic backgrounds in Argentina. The same program was also delivered to 140 private school students in Canada. 42 
The program comprised a one-hour class on the basics of transplantation, including history, end-stage organ failure, waiting lists, brain death, organ donors, the opinion of individuals of monotheist faiths and different messages to the public. The understanding of this critical subject shown by children aged from 10 to 16 years was remarkable. A questionnaire administered after the class showed that pupils from both countries and various socioeconomic backgrounds clearly understand the concepts that had been explained and had a good grasp of the problem. The success of this educational program suggests that state officials responsible for education and public health should consider making education about transplantation, including messages that might change social attitudes to organ and tissue donation, a necessary feature of the school curriculum (Cantarovich, 2014; Gonzalez-Mena \& Pulido-Tobiassen, 1999; Cantarovich, Cantarovich, Falco, Revello, Legendre \& Herrera-Gayol, 2010; Cantarovich, 2010).

\section{Discussion}

The growing medical success of transplantation combined with the increase in transplant waiting list mortality is a serious public health problem. Organ shortages have persisted for decades practically unchanged, and throughout the public education strategy has fundamentally relied on the slogan "Donation is the gift of life". Despite the fact that a change in social attitudes and behavior is needed, attempts to address to solve this serious health problem have until now focused on legal solutions and changes to medical criteria for acceptance of donations. So far no attempts have been made to modify public education programs in order to boost donation rates (Matas \& Hays, 2015; Arnold, Bartlett, Bernat, Colnna, Dafoe, Dubler, Gruber, Kahn, Luskin, Nathan, Orloff, Prottas, Shapiro, Ricordi, Youngner \& Delmonico, 2002; Lawlor, Kerridge, Ankeny \& Billson, 2007).

Recently, McCormic, Held and Chertow, 2018, noted that 43,000 patients per year die whilst waiting for a transplant, a higher number than die due to homicide, Parkinson's disease or HIV, and roughly similar to the death toll from suicide. The kidney shortage kills more people than all gun deaths combined. They suggested the approach recommended by the National Kidney Foundation (NKF), which involves removing disincentives to donation by compensating donors for lost wages, child care and travel expenses incurred as a result of donation. They also proposed an "Organ Donor Clarification Act" and pilot tests of incentives such as a lifetime of free health insurance, educational benefits, student loan forgiveness or pensions contributions, instead of pure cash. They do not consider the possibility of achieving a change in donation behavior through a new, updated and helpful public education program.

The controversial proposal of economic incentives to the donors, it is constantly in force as is shown in a recent article of the Washington Post" "Should we allow an organ market?" The main concepts stated: "Others argue that it would be in the government's financial interest to establish an organ market. In a letter to the Washington Post in December, Ike Brannon of the Organ Reform Group and Network argued that "paying \$50,000 to a donor would not only provide a healthy, viable kidney for everyone who needs one but would also save the government more than $\$ 100$ billion over the next decade [in dialysis costs" (Symons, 2019).

Given that a change in social education approach is one way of trying to address the current organ shortage, it is interesting to remark the concept that rational concerns have less influence on individual donation behavior than irrational concerns such as fear of mutilation or death and lack of confidence in doctors (Morgan, Stephenson, Harrison, Aifi, \& Long, 2008; Kopfman, Smith, Ah Yun \& Hodges, 1998).

An educational program developed by experts in sociology, psychology and theology might modify the inappropriate behavior of society and the tragic consequences of the failure of current approaches to increasing the supply of organs for transplantation.

Also, the perception of the benefits that organ transplantation generates in health budgets in relation to the costs of these patients in dialysis treatments was mentioned as having the greatest impact on attitudes and intentions (Deedat, Kente \& Morgan, 2013; D’Alessandro, Peltier \& Dahl, 2012).

As Shoenberg has commented, we believe that youth education about organ donation in schools, colleges and universities could be a challenge to improve current feelings towards organ donation if efficient educational measures are established in a universal and rational way.

\section{Conclusions}

The persistent organ shortage constitutes an acute public health crisis. It is indisputable that patients will continue to die on transplant waiting lists unless something will be done. We need to accept that social attitudes to donation and rates of donation have remained stubbornly inadequate through the years. A rational analysis indicates that public education programs in this area have been relatively ineffective. The search for ways to resolve this problem has so far focused on medical and legal solutions; there has not yet been an attempt to change public attitudes and behavior by changing the approach to public education. It is worth asking, should this not be tried? 
The global persistence of an ineffective social response towards organ donation justifies an exhaustive analysis of their causes and the chances of improving current education programs. The maintenance of organ shortage and its sad consequence, the constant increase of patients mortality on the waiting list require as a crucial responsibility for those worldwide responsible for education programs, to perform a rational revision of the teaching and methodology structure of social education on organ donation.

\section{References}

Abadie, A., \& Gay, S. (2006). The impact of presumed consent legislation on cadaveric organ donation: A crosscountry study. Journal of Health Economics, 25, 599-620.

Aboud, F. E., Tredoux, C., Tropp, L. R., Spears Brown, C., Niens, U, \& Noor, N. M. (2012). Interventions to reduce prejudice and enhance inclusion and respect for ethnic differences in early childhood: A systematic review. Developmental Review, 32(4), 307-336.

Abouna, G. M. (2008). Organ shortage crisis: problems and possible solutions. Transplant Proceedings, 40(1), 34-38.

Alexander, J. W. \& Zola, J. C. (1996). Expanding the donor pool: use of marginal donors for solid organ transplantation. Clinical Transplantation, 10, 1-19.

Arnold, R., Bartlett, S., Bernat, J., Colnna, J., Dafoe, D., Dubler, N., Gruber S., Kahn J., Luskin R., Nathan H., Orloff, S., Prottas, J., Shapiro, R., Ricordi, C., Youngner, S. \& Delmonico, F. L. (2002). Financial incentives for cadaver organ donation: an ethical reappraisal. Transplantation, 73(8), 1361-1367.

Aykas, A., Uslu, A., \& Şimşek, C. (2015). Mass media, online social network, and organ donation: old mistakes and new perspectives. Transplant Proceedings, 47(4), 1070-1072. doi:10.1016/j.transproceed.2014.09.182, 34

Bardell, T., Childs, A. L., \& Hunter, D. J. (2002). Organ donation: a pilot study of knowledge among medical and other university students. Annals of the Royal College of Physicians and Surgeons of Canada, 35(2), 77-80

Bardell T, Hunter DJ, Kent, WD, Jain MK. (2003) Do medical students have the knowledge needed to maximize organ donation rates? Can J Surg. 46(6): 453-457.

Becker, G. S., \& Elias, J. J. (2007). Introducing incentives in the market for live and cadaveric organ donations. Journal of Economic Perspectives, 21(3), 3-24.

Beom, S. K., Yu, S. K., Soon, I. K., Myoung, S. K., Ho, Y. L., Yong-Lim, K., Lee H. Y., Kim Y. L, Kim Ch. D, Yang Ch. W, Choi B. S, Han D. J, Kim Y. S, Kim S. J, Oh H. Y \& Kim D.J, (2007). Outcome of multipair donor kidney exchange by a web-based algorithm. Journal of the American Society of Nephrology, 18(3), 1000-1006.

Cantarovich, F. (2004). The role of education in increasing organ donation. Annals of Transplantation, 9(1), 39-43.

Cantarovich, F. (2010). Organ donation and a new message for all ages: our body is a source of life to be shared. - TTS International Congress. Societal Public Policy. 40.1 : Retrieved from https://tts.org/component/tts/?view=presentation\&id=1042

Cantarovich, F. (2014). Education and organ donation. Potential role of school programs. Transplantation, 98, 838.

Cantarovich, F. (2018). The patient waiting list dilemma. Strategies options to solve a social injustice. Dialysis and Transplantation Open Access, l(1). Retrieved https://chembiopublishers.com/DTOA/DTOARW\%20180004.pdf

Cantarovich, F. Bacqué, M.C., Casadei, D. (2000). Organ transplantation in Argentina. Clin Transpl 2000, 344-345.

Cantarovich, F., Cantarovich, M., Falco, E., Revello, R., Legendre, C. \& Herrera-Gayol, A. (2010) Education on organ donation and transplantation in elementary and high schools: formulation of a new proposal. Transplantation, 89(9), 1167-1168.

Cantarovich, F., Heguilen, R., Abbud Filho, M., Duro-Garcia, W., Fitzgerald, R., Mayrhofer-Reinhartshuber, D., Lavitrano ML \& Esnault, V. L. M. (2007). An international opinion poll of well-educated people regarding awareness and feelings about organ donation for transplantation. Transplant International, 20(6), 512-518.

Chatterjee, P., Venkataraman, A. S., Vijayan, A., Wellen, J. R., \& Martin, E. G. (2015). The effect of state policies on organ donation and transplantation in the United States. JAMA Internal Medicine, 175(8), 1323-1329.

Cornwall, J., Schafer, C., Lal, N., D’Costa, R., Nada-Raja, S. (2015). New Zealand university students' knowledge and attitudes to organ and tissue donation. New Zealand Medical Journal, 128(1418), 70-79.

Cronin, A. J. (2013). Ethical and legal issues related to the donation and use of nonstandard organs for transplants. Anesthesiology Clinics, 31 (4), 675-687.

D'Alessandro, A. M., Peltier, J. W., \& Dahl, A. J. (2012). The impact of social, cognitive and attitudinal dimensions on college students' support for organ donation. American Journal of Transplantation, 12, 152-161.

Dalal, A. R. (2015). Philosophy of organ donation: Review of ethical facets. World Journal of Transplantation, 5(2), 44-51. 
Davis, J. (1991). Ninety-four percent awareness and still not enough donors; can public education increase organ donation? Surgeon General's Workshop on increasing organ donation. Washington, DC. [Online] Available at: https://profiles.nlm.nih.gov/ps/access/NNBCZG.pdf

de Klerk, M., Keizer, K. M.,. Claas F H., Witvliet, M., Haase-Kromwijk, B. J., \& Weimar, W. (2005). The Dutch national living donor kidney exchange program. American Journal of Transplantation, 5(9), 2302-2305.

Deck, C. \& Kimbrough, E. O. (2013). Do market incentives crowd out charitable giving? Journal of Socio-Economics, 47, 16-24.

Deedat, S., Kente, C.H, \& Morgan, M.O. (2013). What are effective approaches to increasing rates of organ donor registration among ethnic minority populations: a systematic review. BMJ Open, 3, e003453

Essman, C. C., \& Lebovitz, D. J. (2005). Donation education for medical students: enhancing the link between physicians and procurement professionals. Progress in Transplantation, 15(2), 124-128.

Furer, P., \& Walker, J. (2008). Death anxiety: A cognitive-behavioral approach. Journal of Cognitve Psychotherapy, 22(2), 167-182.

Gebel, H., \& Bray, R. (2008). Approaches for transplanting the sensitized patient: biology versus pharmacology. Nephrology Dialysis Transplantation, 23(8), 2454-2457.

Gentry S, Segev D, Simmerling M., Montgomery R. (2007) Expanding Kidney Paired Donation Through Participation by Compatible Pairs. Am J Transplant 7 (10), 2361-2370.

Gonzalez-Mena, J., \& Pulido-Tobiassen, D. (1999). Teaching diversity: a place to begin. Early Childhood Today. Retrieved from: https://www.scholastic.com/teachers/articles/teaching-content/teaching-diversity-place-begin-0

Hanto, D. W., Peters, T. G., Howard, R. J., \& Cornell, D. (2005). Family disagreement over organ donation. Virtual Mentor, 1;7(9). doi:10.1001/virtualmentor.2005.7.9.ccas2-0509

Humphries, H. L., Conrad, B. K., Berry, R., Reed, S., \& Jennings, C. M. (2009). Framing the gift of life: An empirical examination of altruism, social distance and material incentives in non-directed kidney donor motivation. Journal of Nephrology Social Work, 31, 19-26.

Kopfman, J. E., Smith, S. W., Ah Yun, J. K., \& Hodges, A. (1998). Affective and cognitive reactions to narrative versus statistical evidence organ donation messages. Journal of Applied Communication Research, 26(3), 279-300.

Lawlor, M., Kerridge, I., Ankeny, R., \& Billson, F. (2007). Public education and organ donation: untested assumptions and unexpected consequences. Journal of Law and Medicine, 14(3), 360-366.

Le Dinh, H., Monard, J., Delbouille, M. H., Hans, M. F., Weekers, L., Bonvoisin, C., Joris J, Lauwick S, Kaba A, Ledoux D, de Roover A, Honoré P, Squifflet JP, Meurisse M, Detry O (2014) A more than $20 \%$ increase in deceased-donor organ procurement and transplantation activity after the use of donation after circulatory death Transplant Proceedings, 46(1), 9-13.

McCormic, F., Held, P. J. \& Chertow, M. (2018). The terrible toll of the kidney shortage. Journal of the American Society of Nephrology, 29(12), 2775-2776. doi: 10.1681/ASN.2018101030

Matas, A. J., \& Hays, R. E. (2015). Transplantation: Little effect of state policies on organ donation in the USA. Nature Reviews Nephrology, 11(10), 570-572.

Matesanz, R., \& Miranda, B. (1995). Profile of the Spanish transplant coordinator. Transplant Proceedings, 27(4), 2389-2390.

Mocan, N., \& Tekin, E. (2007). The determinants of the willingness to donate an organ among young adults: evidence from the United States and the European Union. Social Science \& Medicine, 65(12), 2527-2538.

Montgomery, R. A., Zachary, A. A., Ratner, L. E., Segev, D. L., Hiller, J. M., Houp, J.,.. Warren, D. S. (2005). Clinical results from transplanting incompatible live kidney donor/recipient pairs using kidney paired donation. JAMA, 294(13), 1655-1663.

Morgan, S. E., Harrison, T. R., Afifi, W. A., Long, S. D., \& Stephenson, M. T. (2008a). In their own words: the reasons why people will (not) sign an organ donor card. Health Communication, 23(1), $23-33$.

Morgan, S. E., Harrison, T. R., Long, S. D., Afifi, W. A., Stephenson, M. T., \& Reichert, T. (2005). Family discussions about organ donation: how the media influences opinions about donation decisions. Clinical Transplantation, 19(5), 674-682.

Morgan, S. E., Stephenson, M. T., Harrison, T. R., Aifi, W. A., \& Long, S. D. (2008b). Facts versus 'Feelings': how rational is the decision to become organ donor? Journal of Health Psychology, 13(5): 644-658.

National Kidney Foundation. (2003). Financial incentives for organ donation. Retrieved from: https://www.kidney.org/news/newsroom/positionpaper03

Newton, D. (2011). How does the general public view posthumous organ donation? A meta-synthesis of the qualitative literature. BMC Public Health, 11, 791.

O'Carroll, R. E., Foster, C., McGeechan, G., Sandford, K., \& Ferguson, E. (2011). The "ick" factor, anticipated regret, and willingness to become an organ donor. Health Psychology, 30(2), 236-245. 
Ojo, A. O. (2005) Expanded criteria donors: process and outcomes. Seminars in Dialysis 18(6), 463-468.

Radunz, S., Benkö, T., Stern, S., Sane, F. H. R., Paul, A., \& Kaiser, G. M (2015). Medical students' education on organ donation and its evaluation during six consecutive years: results of a voluntary, anonymous educational intervention study. European Journal of Medical Research, 20(1), 23. doi:10.1186/s40001-015-0116-6

Rapaport, F. T. (1986). The case for a living emotionally related international kidney donor exchange registry. Transplant Proceedings, 18, 5-9.

Robertson, J. A. (2012). Delimiting the donor: The dead donor rule. Hasting Center First published: 06 March 2012 Retrieved from: https://doi.org/10.2307/3527865

Ross, L. F., Rubin, D. T., Siegler, M., Josephson, M. A., Thistlethwaite, J. R. Jr, \& Woodle, E. S. (1997). Ethics of a paired-kidneyexchange program. New England Journal of Medicine, 336, 1752-1755.

Shmugarajahadan K, Villania V; Madariaga ML, Shalhoubd J, Michelab SG (2014) Current progress in public health models addressing the critical shortage. Int J of Surgery, 12(12):1363-1368

Shoenberg, R. S. (1991). The Surgeon General's workshop on increasing organ donation: Background Papers. "Planting the seed: Organ transplantation education for children, youth and young adults". Reports of the Surgeon General. Retrieved from: https://profiles.nlm.nih.gov/ps/access/NNBCZK.pdf

Stanford Encyclopedia of Philosophy. (2003/2015). Autonomy in moral and political philosophy. Retrieved from: https://plato.stanford.edu/entries/autonomy-moral/)

Symons X. (2019). Should we allow an organ market? BioEdge, bioethics news from around the world 19 Jan. Retrieved from https://www.bioedge.org/bioethics/should-we-allow-an-organ-market/12939

Tabarrok, A. T. (2001). A moral solution to the organ shortage. Independent Institute. February 19. Retrieved from: http://www.independent.org/news/article.asp?id=283

Thagard, P. (2012). Should you fear death? Because minds are brains, death should not be scary. Physiology Today. Retrieved from: https://www.psychologytoday.com/us/blog/hot-thought/201206/should-you-fear-deat

University of Chicago Medical Center. (2003). Conference considers compensating organ donors. Retrieved from: https://www.eurekalert.org/pub_releases/2003-05/uocm-ccc051503.php

US Department of Health and Human Services. (2018). Government information on organ donation and transplantation. Organ donation and transplantation statistics: graph data. Retrieved from: https://www.organdonor.gov/statistics-stories/statistics/data.htm

Van Dijk, G., \& Hilhorst, M. T. (2007). Financial incentives for organ donation. An investigation of the ethical issues. Council for Public Health and Health Care. Ethics and Health Monitoring Report 2007/3. The Hague: Centre for Ethics and Health. Retrieved from: https://www.ceg.nl/uploads/publicaties/Orgaandonatie_Engels.pdf

Verheijde, J. L., Rady, M. Y., \& McGregor, J. L. (2007). Negative attitudes and feelings of well- educated people about organ donation for transplantation. Transplant International, 20(10), 906-907.

Working Group on Incentives for Living Donation. (2012). Incentives for organ donation: Proposed standards for an internationally acceptable system. American Journal of Transplantation, 12(2), 306-312. 